\title{
Studies on Activation of Systemic Acquired Resistance (SAR) by Heterocyclic Compounds Having Azole Groups in Vigna radiata (L.) Wilczek.
}

\author{
Indu RAV I', Shipra VARSHNEY², Gunjan SHARMA³, Vandana \\ DWIVEDI ${ }^{3}$, Kambaska Kumar BEHERA ${ }^{2 *}$ \\ ${ }^{1}$ IGNOU Regional Centre, Jaipur-302020, Rajasthan, India \\ ${ }^{2}$ Banasthali University, Department of Bioscience and Biotechnology, Banasthali-304022, \\ Rajasthan, India; kambaska@yahoo.co.in ("corresponding author) \\ ${ }^{3}$ Agra College, Department of Chemistry, Agra-2008 (U.P.)
}

\begin{abstract}
Heterocyclic compounds are known to activate the defense response or resistance in plants. In order to study their effect as activators of systemic acquired resistance (SAR), two series of heterocyclic compounds having azole group were used for the present study i.e., substituted triazolothiadiazoles and thiazolidine thioureas to obtain new compounds with improved biological activities in mung beans (Vigna radiata (L.)Wilczek, is an important pulse crop of India. These compounds could be used as a solution to chemically mediated disease control both at the farm level as well as chemical fungicides. For this polyphenol content, flavonoid content, PAL activity, peroxidase activity and protein content were determined in control and after chemical treatment in mung beans var. 'RMG-344. The results indicated significant changes and a distinct role of polyphenols, flavonoids, PAL, peroxidase and proteins in the defense response of mung beans after treatment with these chemicals.
\end{abstract}

Keywords: heterocyclic compounds, plant activators, systemic acquired resistance

\section{Introduction}

Plants continuously defend themselves against attack from bacteria, viruses, fungi, invertebrates and other plants. Each plant possesses both a preformed and an inducible defense capacity. Infection of resistant plant by pathogens triggers a complex series of biochemical and cellular events at or near the infection site which is called hypersensitive response (HR). The hypersensitive response is characterized by localized cell and tissue death at the site of infection (Van Loon, 1997). These local responses often triggers non-specific resistance throughout the plants, known as systemic acquired resistance (SAR), providing durable protection against challenge infection by the broad range of pathogens (Fritig et al., 1998; Stanetty et al., 2005; Sticher et al., 1997; Van Loon, 1997). SAR is a whole plant response, during which the entire plant becomes highly resistant to a large number of pathogens. SAR can be distinguished from other disease resistance response by both the spectrum of the pathogen protection and the associated changes in the gene expression of a set of genes called SAR genes (Ward et al., 1991).

SAR was first described as a response to pathogen infection. Subsequently it has been found that treatment of plants with low molecular weight molecules can also induce SAR. Natural signaling molecules are SA (salicylic acid), JA (Jasmonic acid), systemin and elicitors are the components of biological induction.

The use of chemicals to activate SAR provides novel alternatives for disease control in agronomic system as well tools for the elucidation of the SAR signal transduction cascade (Neuenschwander et al., 1995).Various chemicals have been discovered that seems to act at various points in these defense activating networks and mimic all or parts of the biological activation of resistance (Kessmann et al., 1994). To be considered an activator first, the compound or its significant metabolites should not exhibit direct antimicrobial activity, second it should induce resistance against the same spectrum of pathogen as in biological activated SAR, and third, it should induce the expression of the same marker gene as evident in pathogen activated SAR. Earlier several chemicals were used such as silicon, phosphate, 2-thiouracil, polyacrylic acid, nucleic acids, and fosethyl-Al which have been reported as potential activators of resistance but have failed to fulfill the criteria which were given by Kessmann et al. (1994). Other compounds DL-3-aminobutanoic acid or probenzole, have been shown to slightly induce either PR-1 gene expression or resistance against one or two pathogens. The chemicals 2, 6-dichloroisonicotinic acid and its methyl esters (both are referred to as INA) were the first synthetic compounds shown to activate SAR, thus providing broad-spectrum disease resistance (Métraux et al., 1991; Vernooji et al., 
1995). Now, the synthetic chemical benzo $(1,2,3)$ thiadiazole-7-carbothioic acid S-methyl ester (BTH) was used as a potent SAR activator (Friedrich et al., 1996; Gorlach et al., 1996; Lawton et al., 1996) that supplies protection in the field.

Polyphenols are commonly present in certain edible and non edible plant tissue and have aroused a great deal of interest recently. The antioxidant activity of polyphenols is mainly due to their redox properties, which can play an important role in absorbing and neutralizing free radicals, quenching oxygen, or decomposing peroxidase. Among the diverse roles of polyphenols, they protect the cell constituents against destructive oxidative damage thus limiting the risk of various degenerative diseases associated with oxidative stress (Villano et al., 2005).

Flavonoids are a class of plant secondary metabolites. Structurally they are are characterized by a 15 -carbon (C6-C3-C6) backbone consisting of one oxygenated and two aromatic rings. They are grouped together into subclasses based on their basic chemical structures; the most common ones being flavanols, flavones, flavonols, isoflavones, flavanones, anthocyanins and chalcones.The in vitro studies of flavonoids have displayed anti-oxidant, anti-allergic, anti-inflammatory, anti-microbial and anticancer activities (Winkel-Shirley, 2002).

Phenylalanine ammonia lyase (PAL) is the key enzyme involved in the biosynthesis of polyphenols and flavonoids. PAL activity is known to affect the accumulation of polyphenols and any stress such as fungal pathogen inoculation or mechanical injury alter its level, consequently that of its various other intermediates of phenylpropanoid pathway and hence the end product of the pathway like flavonoids, coumarins, chlorogenic acid etc. (Attridge et al., 1971).

A number of defense related proteins are known to be induced in response to pathogen infection/ elicitors/ any stress condition, e.g. chitinase, $\beta$-1,3-glucanase, peroxidase etc. Among the proteins induced during the host plant defense, plant peroxidases (EC1.11.1.7) are well known. They belong to a large multigene family and participate in a broad range of physiological processes, such as lignin and suberin formation, cross-linking of cell wall components and the synthesis of phytoalexins, or participate in the metabolism of ROS and RNS, both switching on the hypersensitive response (HR), a form of programmed host cell death at the infection site associated with limited pathogen development.

Mung bean (Vigna radiata) is an important pulse crop of India and belongs to family Fabaceae. Mung bean, also known as green bean, mung, mongo, moong, moog dal, mash bean, munggo or monggo, green gram, golden gram and green soy. It is native to Bangladesh, India and Pakistan. Besides, it is also cultivated in Indonesia, China, Myanmar, Nepal and Sri Lanka. It is important source of dietary protein being commercially cultivated in states like Rajasthan, Uttarpradesh., Bihar, Haryana, Punjab. When split, the bean is known as moong daal. In India and Bangladesh, it is grown during two seasons: Rabi (starting in November) and Kharif (Starting in June); some farmers also grow mung bean in summer (starting in March). Mung bean is tropical or sub tropical crop and require warm temperature (optimally around $30-35^{\circ} \mathrm{C}$ ). Areas with annual rainfall of $50-70 \mathrm{~cm}$ are considered best for mung bean cultivation. It requires hot climate and has the capacity to tolerate moisture stress. Loam to sandy loam soils are considered best for the mung bean cultivation. Generally, these beans are eaten either whole or as bean sprouts. They are also used to make soups and desserts. The starch extracted from them is used to make jellies and noodles. Mung beans are known to be very healthy and packed with a variety of nutrients. It has the capacity to fix atmospheric nitrogen through symbiotic Nitrogen fixation. It is also used as green manure crop. Being a short duration crop it also provides an excellent green fodder to the animals.

In view of the above discussions the present study was undertaken to find chemical activators of SAR. Two series of heterocyclic compounds having azole group were used for the present study i.e. substituted triazolothiadiazoles and thiazolidine thioureas to obtain new compounds with improved biological activities. These compounds could be used as a solution to chemically mediated disease control both at the farm level as well as chemical fungicides.

T Series-Substituted Thiazolidinone Thioureas

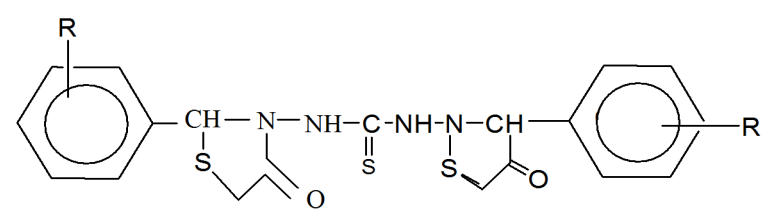

Bis-1,3-(2-(Substituted phenyl-thiazolidin-4one)-3yl) thioureas

\section{P Series-Substituted Triazolothiadiazoles}

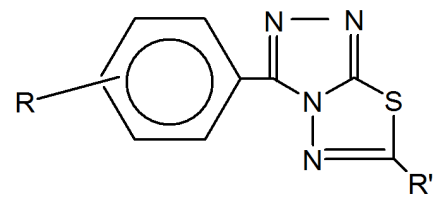

3-Substituted 1, 2, 4-triazolo $(3,4-6)(1,3,4)$ thiadiazoles

\section{Materials and methods}

\section{Plant material}

Seeds of Vigna radiata (Mung) var. 'RMG-344' were procured from Krishi Vigyan Kendra, Banasthali University, Banasthali, Rajasthan. The surface sterilized seeds were grown in sterilized garden soil in plastic pots in the botanical garden, Department of Bioscience and Biotechnology Banasthali University. The seeds germinated with in 2-3 days after sowing and fifteen day's old plants were taken for different experimental assay. 
76

The culture strains of Fusarium oxysporum, Macrophomina phaseolina, Alternaria brassicicola, Trichoderma viridae and Aspergillus niger were obtained from IM$\mathrm{TECH}$, Chandigarh. The lyophilized fungal strains were activated by inoculating in a flask containing Potato Dextrose Broth. This was done under proper aseptic condition in the laminar air flow hood. These flasks were than incubated in the incubator shaker $\left(28 \pm 2^{\circ} \mathrm{C}, 120 \mathrm{rpm}\right)$ for 5 days. The activated fungal strains were kept for further determination of antifungal activity.

\section{Chemicals used for activation of disease resistance}

Two series of heterocyclic compounds having azole group were used for the present study i.e. substituted triazolothiadiazoles and thiazolidine thioureas. The two series of chemicals used for the present study were $T$ series and $P$ series. In the $T$ series: $T_{0}, T_{1}, T_{0-1,}, T_{0-2}$ were used whereas, in $\mathrm{P}$ series- $\mathrm{P}_{0}, \mathrm{P}_{1}, \mathrm{P}_{2}, \mathrm{P}_{3} \mathrm{P}_{4} \mathrm{P}_{6}, \mathrm{P}_{7}$ were used. $T$ series chemicals were dissolved in benzene while for $\mathrm{P}$ series $\mathrm{P}_{0}$ and $\mathrm{P}_{2}$ were dissolved in methanol and the remaining in ethanol. These chemicals were synthesized and provided by the chemistry Department of Agra College, Agra.

\section{Synthesis of chemicals}

\section{T Series-Substituted Thiazolidinone Thiourease}
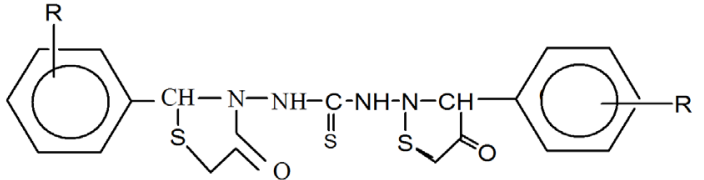

Bis-1,3-(2-(Substituted phenyl-thiazolidin-4-one)3yl) thioureas

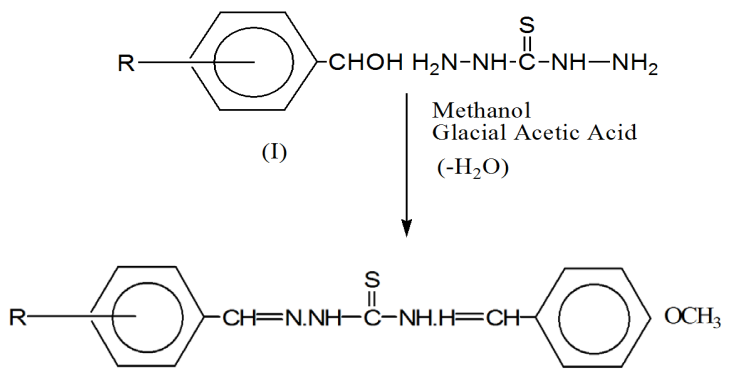

Bis1,3-(aryloxy benzaldehyde hydrazone)thiacarbazinate

(II)

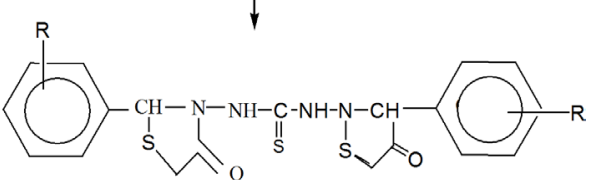

(III)

\begin{tabular}{ccc}
\hline \multicolumn{4}{c}{ Group $(\mathrm{R})$} \\
\hline $\mathrm{T}_{0}$ & $4-\mathrm{OCH}_{3}$ & Previous (II) \\
$\mathrm{T}_{1}$ & $4-\mathrm{OCH}_{3}$ & Final (III) \\
$\mathrm{T}_{-01}$ & $2-\mathrm{C}_{1}, 5-\mathrm{NO}_{2}$ & Previous (II) \\
$\mathrm{T}_{-02}$ & $2-\mathrm{C} 1,5-\mathrm{NO}_{2}$ & Final (III) \\
\hline
\end{tabular}

\section{P Series-Substituted Triazolothiadiazoles}

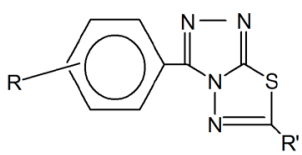

3-Substituted 1, 2, 4-triazolo $(3,4-6)(1,3,4)$ thiadiazoles<smiles>NNNC(=S)NCCNNC(=S)NN</smiles>

(I) Dihydrazinium thiocarbazinate<smiles>[R]C(=O)OCNNC(=S)NN</smiles>

(II) 3-alkyl-4-amino-5-mercaptol,2,4, triazoles<smiles>[R]C(=O)C(=O)OC(=O)O</smiles><smiles>[R]C(=O)Nn1c([R])nnc1S</smiles>

(III) 4 Acetamide-3-alky15-mercapta-1,2,4-triazoles<smiles>[R]c1nn2c([R])nnc2s1</smiles>

(IV) 6-Alkyl/Aryl-3-alkyl-1,2,4-triazolo(3,4,-6)(1,3,4)thiadiazoles

\begin{tabular}{|c|c|c|}
\hline & R Group & R' Group \\
\hline $\mathrm{P}_{0}(\mathrm{II})$ & $\mathrm{OH}_{3} \mathrm{C}-$ & \\
\hline$P_{1}(\mathrm{IV})$ & $\mathrm{OH}_{3} \mathrm{C}-\mathrm{O}-$ & \\
\hline $\mathrm{P}_{2}$ (IV) & $\mathrm{OH}_{3} \mathrm{C}-\mathrm{O}-$ & $\mathrm{OH}_{3} \mathrm{C}-$ \\
\hline $\mathrm{P}_{3}(\mathrm{IV})$ & & $\mathrm{OH}_{3} \mathrm{C}-$ \\
\hline $\mathrm{P}_{4}(\mathrm{IV})$ & & \\
\hline $\mathrm{P}_{6}(\mathrm{III})$ & $\mathrm{OH}_{3} \mathrm{C}-\mathrm{C}$ & \\
\hline $\mathrm{P}_{7}$ (III) & $\mathrm{OH}_{3} \mathrm{C}-\mathrm{O}-$ & $\mathrm{OH}_{3} \mathrm{C} \longrightarrow \mathrm{O}$ \\
\hline
\end{tabular}




\section{Plant growth}

Seeds were surface sterilized in $0.1 \% \mathrm{HgCl}_{2}$ and grown in sterilized garden soil in plastic pots in the botanical garden. Fifteen days old plants were used as experimental material after different time intervals of chemical treatment.

\section{Mode of chemical application}

Chemicals were dissolved in methanol, ethanol and benzene and prepared as stock of $1000 \mathrm{ppm}$ solutions. The working concentration taken was $100 \mathrm{ppm}$ for all the chemicals. The leaf surface of plants was injured mildly with an abrasive and the chemicals were sprayed on plant surface using a TLC sprayer/spay bottle. The plants sprayed with distilled water without chemicals served as control.

\section{Determination of polyphenol content}

Determination of polyphenol content was done using the method of Mc Donald (2001) using gallic acid as standard. One gram of tissue was homogenized in $10 \mathrm{ml}$ of $75 \%$ methanol. The homogenate was centrifuged at 5000 rpm for 25 minutes in a cooling (Remi) centrifuge. The supernatant was used for further assay. Hundred microliters $(100 \mu \mathrm{l})$ of supernatant was mixed with $8.9 \mathrm{ml}$ distilled water and $0.5 \mathrm{ml}$ folin reagent. This reaction mixture was allowed to stay in the dark for 5 minutes. After 5 minutes, $1.0 \mathrm{ml}$ of $25 \%$ sodium bicarbonate was added. The absorbance was read against blank at $725 \mathrm{~nm}$ using UV-visible spectrophotometer. The standard curve was prepared using gallic acid of $1 \mathrm{mg} / \mathrm{ml}$ concentrations.

\section{Determination of flavonoid}

Aluminium chloride colorimetric method was used for total flavonoids determination according to the method of Chang et al. (2002). One gram of plant tissue was homogenized in $10 \mathrm{ml}$ of $96 \%$ ethanol. Each plant extract $0.5 \mathrm{ml}$ were separately mixed with $1.5 \mathrm{ml}$ of ethanol, 0.1 $\mathrm{ml}$ of $10 \%$ aluminium chloride, $0.1 \mathrm{ml}$ of $1 \mathrm{M}$ potassium acetate and $2.8 \mathrm{ml}$ of distilled water. It was kept at room temperature for 30 minutes and the absorbance of the reaction mixture was measured at $415 \mathrm{~nm}$ using a double beam UV-Visible spectrophotometer (Hitachi, U-4100). The standard curve was prepared using quercetin of $1 \mathrm{mg} /$ $\mathrm{ml}$ concentration.

\section{Determination of Phenylalanine Ammonia Lyase} (PAL)

The PAL activity was determined according to the method of Camm and Towers (1973).

\section{Preparation of extract}

The crude enzyme extract was prepared by homogenizing one gram of plant tissue in $15 \mathrm{ml}$ of borate buffer $(\mathrm{pH}$ $8.8)$ at $4^{\circ} \mathrm{C}$. The homogenate was centrifuged at 10,000 $\mathrm{g}$ for 15 minutes at $4^{\circ} \mathrm{C}$. The supernatant was taken for further purification by the ammonium sulphate precipitation.

\section{Determination of peroxidase}

The peroxidase activity was determined using the method given by Putter (1974). One gram of plant tissue was crushed in $3 \mathrm{ml}$ of $0.1 \mathrm{M}$ phosphate buffer $(\mathrm{pH} 7.0)$ by grinding with a pre-cooled mortar pestle at $4^{\circ} \mathrm{C}$. Centrifuge the homogenate at $18000 \mathrm{~g}$ at $5^{\circ} \mathrm{C}$ for 15 minutes. Enzyme extract $0.1 \mathrm{ml}$ was taken in a cuvette, to this 20 $\mathrm{mM}$ guaiacol solution and hydrogen peroxide solution was added. The mixture was mixed and the cuvette placed in spectrophotometer. The absorbance was allowed to increase by 0.05 and the time which was required in minutes $(\Delta \mathrm{t})$ to increase the absorbance by 0.1 was noted. Absorbance was measured at $436 \mathrm{~nm}$. Since the extinction coefficient of guaiacol dehydrogenation product at $436 \mathrm{~nm}$ under the conditions specified is 6.39 per micromole, the enzyme activity per liter of extract is calculated as below:

$$
\text { Enzyme activity units } / \text { liter }=\frac{3.18 \times 0.1}{6.39 \times 1 \times \Delta t \times 0.1} \times 1000
$$

\section{Histochemical detection of hydrogen peroxide by $D A B$}

The histochemical detection of hydrogen peroxide by $\mathrm{DAB}$ was done using the method given by ThordalChristensen et al. (1997). The leaves of 15 days plants were taken and placed in $1 \mathrm{mg} / \mathrm{ml}$ concentration of 3, 3-diaminobenzidine (DAB)-HCl pH 3.8 and incubated for 8 hours prior to sampling. After 8 hours samples were placed in boiling $96 \%$ ethanol for 10 minutes at $100^{\circ} \mathrm{C}$. Then the samples were stored in $96 \%$ ethanol. The presence of reddish brown coloured patches on the leaves indicated the site of $\mathrm{H}_{2} \mathrm{O}_{2}$ production and peroxidase activity.

\section{Determination of total protein}

The total proteins were determined according to the method of Lowry et al. (1951). One gram tissue was homogenized in $4 \mathrm{ml}$ of $0.1 \mathrm{M}$ phosphate buffer. Homogenized tissue was centrifuged at $5000 \mathrm{rpm}$ for 10 minutes at $4^{\circ} \mathrm{C}$. One $\mathrm{ml}$ of supernatant was taken for assay. Bovine Serum albumin (BSA) of $1.0 \mathrm{mg} / \mathrm{ml}$ as was taken as standard.

\section{SDS-PAGE for protein estimation}

Qualitative detection of total protein was done by SDS-PAGE (Laemmli, 1970). Samples from control and chemically treated plants were run in 10\% gel for comparison.

\section{Detection of antifungal activity}

The different media for culture of fungal strains were prepared and autoclaved at $15 \mathrm{lb} /$ inch and pressure $\left(121^{\circ} \mathrm{C}\right)$ for 15 minutes in petriplates.

For determining antifungal activity PDA medium was used. After solidification agar surface was inoculated with $150 \mu \mathrm{l}$ suspension of phyto-pathogenic fungal suspension. After that $0.5 \mathrm{~mm}$ paper sterile discs were placed on the inoculated agar surface and the chemicals were transferred to the discs drop wise using a micropipette under steril- 
78

ized conditions. The plates were incubated for 48 hours at $30^{\circ} \mathrm{C}$ in the incubator. The cultures were examined for the presence of clear inhibition zone around the disc after 24-48 hours.

\section{Result and discussion}

\section{Chemicals used for activation of $S A R$}

Two series of heterocyclic compounds having azole group were used for the present study i.e. substituted triazolothiadiazoles and thiazolidine thioureas. The two series of chemicals used for the present study were T series and $\mathrm{P}$

Tab. 1. Quantitative changes in Polyphenol content in control and chemically treated plants of Vigna radiata var. 'RMG-344' for P Series

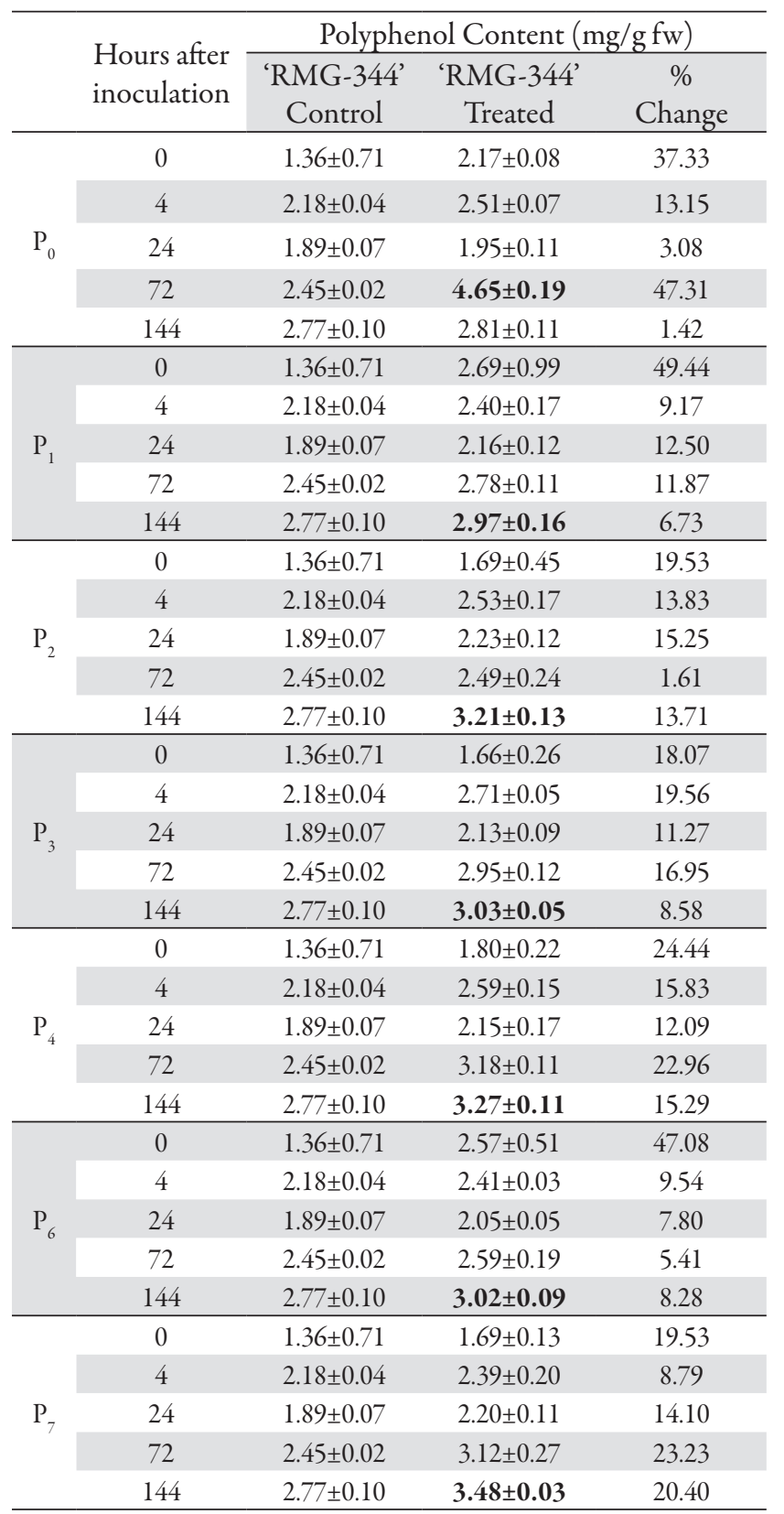

series. In the $T$ series- $T_{0} T_{1} T_{0-1} T_{0-2}$ were used whereas, in $\mathrm{P}$ series- $\mathrm{P}_{0}, \mathrm{P}_{1}, \mathrm{P}_{2}, \mathrm{P}_{3}, \mathrm{P}_{4}, \mathrm{P}_{6}, \mathrm{P}_{7}$ were used. Chemicals were dissolved in appropriate solvents and prepared as stock of 1000 ppm solutions. The working concentration taken was 100 ppm for all the chemicals. The chemical solution was sprayed on plants after rubbing gently with an abrasive to facilitate entry of chemicals.

\section{Polyphenol content}

The polyphenol content was determined in Vigna radiata var. 'RMG-344' at different time intervals after chemical treatment using gallic acid as standard. The phenolic content of methanolic extract of leaves of both plants was calculated as gallic acid equivalents. From the data given in Tab. 1 and 2, it is found that the polyphenol content was higher in the chemically treated plants as compared to the control. The phenolic content varied from $1.36 \mathrm{mg} / \mathrm{g}$ fw to $4.65 \mathrm{mg} / \mathrm{g}$ fw in Vigna radiata. Among the two series the maximum polyhenol content was obtained in $\mathrm{P}$ series for $\mathrm{P}_{0}$ and in $\mathrm{T}$ series for $\mathrm{T}_{-}{ }_{01}$ at 72 hours whereas maximum $\%$ change was obtained in $\mathrm{P}$ series for $\mathrm{P}_{1}$ at 0 hour and in $\mathrm{T}$ series for $\mathrm{T}_{1}$ at 144 hours in Vigna radiate (Tab. 1 and 2 ).

This is an agreement with results reported by Kuc (1982). Changes in phenolic acid content in tomato fruits in response to pathogen attack was determined by Ruelas et al. (2006). A number of phenolic acids were synthesized or significant increase in the concentration of phenolic acids was observed after inoculation with spores of Alter-

Tab. 2. Quantitative changes in Polyphenol content in control and chemically treated plants of Vigna radiata var. 'RMG-344' for T Series

\begin{tabular}{|c|c|c|c|c|}
\hline & \multirow{2}{*}{$\begin{array}{l}\text { Hours after } \\
\text { inoculation }\end{array}$} & \multicolumn{3}{|c|}{ Polyphenol Content (mg/g fw) } \\
\hline & & $\begin{array}{c}\text { 'RMG-344' } \\
\text { Control }\end{array}$ & $\begin{array}{c}\text { 'RMG-344' } \\
\text { Treated }\end{array}$ & $\begin{array}{c}\% \\
\text { Change }\end{array}$ \\
\hline \multirow{5}{*}{$\mathrm{T}_{0}$} & 0 & $2.12 \pm 0.14$ & $2.59 \pm 0.11$ & 18.15 \\
\hline & 4 & $2.52 \pm 0.09$ & $2.63 \pm 0.06$ & 4.18 \\
\hline & 24 & $1.89 \pm 0.08$ & $2.59 \pm 0.07$ & 27.03 \\
\hline & 72 & $1.70 \pm 0.05$ & $2.72 \pm 0.13$ & 37.50 \\
\hline & 144 & $1.42 \pm 0.12$ & $2.66 \pm 0.08$ & 46.62 \\
\hline \multirow{5}{*}{$\mathrm{T}_{-01}$} & 0 & $2.12 \pm 0.14$ & $2.23 \pm 0.14$ & 4.93 \\
\hline & 4 & $2.52 \pm 0.09$ & $2.81 \pm 0.10$ & 10.32 \\
\hline & 24 & $1.89 \pm 0.08$ & $2.61 \pm 0.14$ & 27.59 \\
\hline & 72 & $1.70 \pm 0.05$ & $3.55 \pm 0.26$ & 52.11 \\
\hline & 144 & $1.42 \pm 0.12$ & $2.86 \pm 0.08$ & 50.35 \\
\hline \multirow{5}{*}{$\mathrm{T}_{-02}$} & 0 & $2.12 \pm 0.14$ & $2.32 \pm 0.52$ & 8.62 \\
\hline & 4 & $2.52 \pm 0.09$ & $2.64 \pm 0.04$ & 4.55 \\
\hline & 24 & $1.89 \pm 0.08$ & $2.34 \pm 0.18$ & 19.23 \\
\hline & 72 & $1.70 \pm 0.05$ & $2.35 \pm 0.49$ & 27.66 \\
\hline & 144 & $1.42 \pm 0.12$ & $3.01 \pm 0.31$ & 52.48 \\
\hline \multirow{5}{*}{$\mathrm{T}_{1}$} & 0 & $2.12 \pm 0.14$ & $2.33 \pm 0.03$ & 9.01 \\
\hline & 4 & $2.52 \pm 0.09$ & $3.15 \pm 0.04$ & 20.00 \\
\hline & 24 & $1.89 \pm 0.08$ & $3.07 \pm 0.38$ & 38.44 \\
\hline & 72 & $1.70 \pm 0.05$ & $3.33 \pm 0.04$ & 48.95 \\
\hline & 144 & $1.42 \pm 0.12$ & $3.42 \pm 0.12$ & 58.48 \\
\hline
\end{tabular}


naria alternata. The induction of phenolic compounds as part of the defense system against pathogen using elicitors has also been demonstrated by Pearce et al. (1998).

\section{Flavonoid}

Total flavonoid content was determined by aluminium chloride colorimetric method and expressed in terms of

Tab. 3. Quantitative changes in Flavonoid content in control and chemically treated plants of Vigna radiata var. 'RMG-344' for P Series

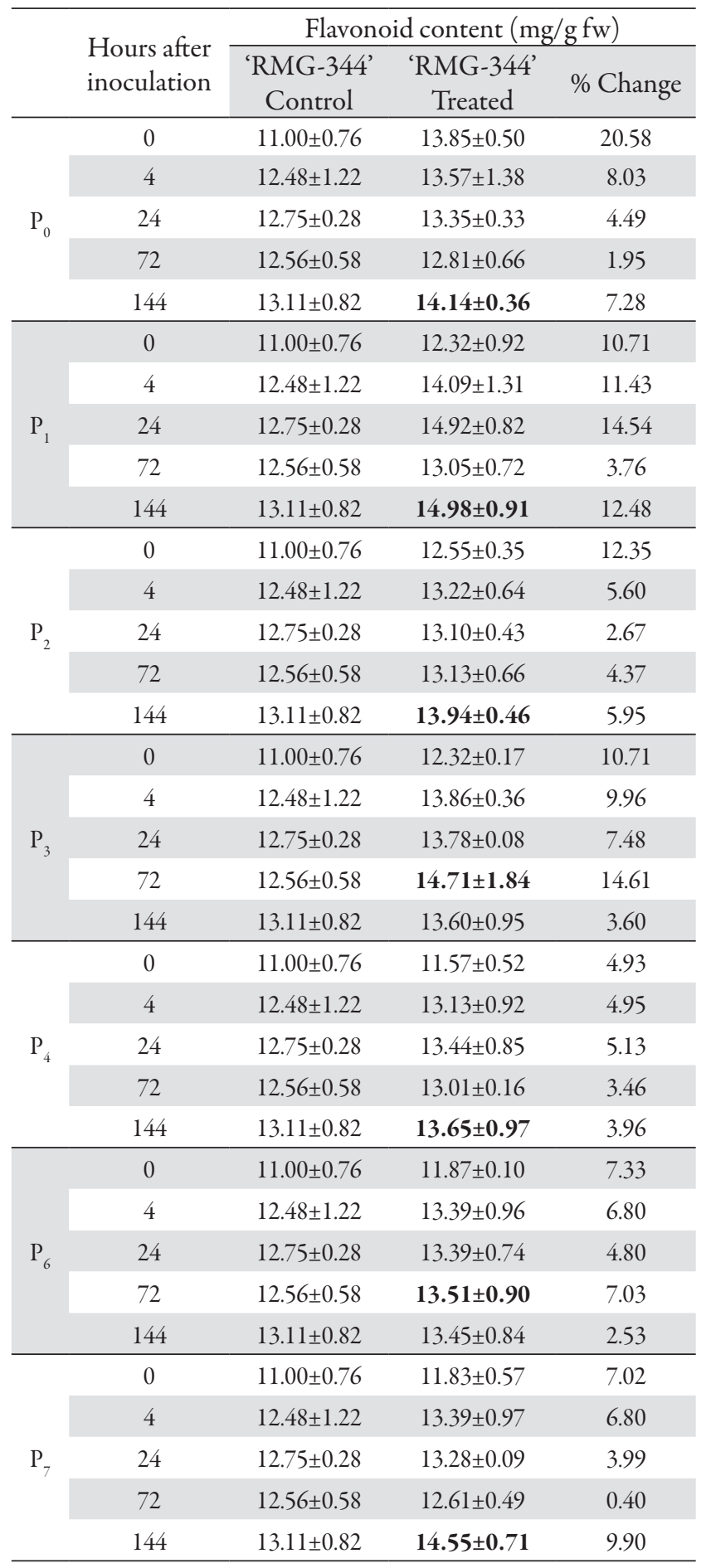

qurecetin equivalent in $\mathrm{mg} / \mathrm{g}$ fw using standard graph of qurecetin. The data revealed that the total flavonoid content was in general higher in the treated plants as compared to control. Maximum flavonoid content for Vigna radiata was obtained for $\mathrm{P}_{1}$ in $\mathrm{P}$ series and for $\mathrm{T}_{0}$ in $\mathrm{T}$ series at 144 hours whereas maximum \% change was obtained in $\mathrm{P}$ series for $\mathrm{P}_{0}$ at 0 hour and in $\mathrm{T}$ series for $\mathrm{T}_{0}$ at 144 hours (Tab. 3 and 4 ).

The total flavonoid and polyphenol compounds were detected in ethanol and water extracts of leaves and stem and it was suggested by Huang et al. (2005) that they might contribute directly to antioxidant action. The compounds such as flavonoid, which contain hydroxyls, are responsible for the radical scavenging effect in the plants (Das and Pereira, 1990; Younes, 1981). According to our studies, the high contents of these phytochemicals can explain its high radical scavenging activity and the role of polyphenols and flavonoids in activation of the defense response.

\section{Phenyl alanine Ammonia Lyase (PAL)}

Determination of PAL activity was recorded and shows that there is a general increase in activity of chemically treated plants with respect to control.

The PAL activity for Vigna radiata showed the maximum activity for $\mathrm{P}_{2}$ in $\mathrm{P}$ series and for $\mathrm{T}_{-01}$ in $\mathrm{T}$ series at 72 and 24 hours, respectively whereas the maximum \% change was obtained for $\mathrm{P}_{2}$ at 144 hours and in T series it was found for same sample at same hours (Tab. 5 and 6).

Tab. 4. Quantitative changes in Flavonoid content in control and chemically treated plants of Vigna radiata var. 'RMG-344' for T Series

\begin{tabular}{|c|c|c|c|c|}
\hline & \multirow{2}{*}{$\begin{array}{l}\text { Hours after } \\
\text { inoculation }\end{array}$} & \multicolumn{3}{|c|}{ Flavonoid content $(\mathrm{mg} / \mathrm{g} \mathrm{fw})$} \\
\hline & & $\begin{array}{c}\text { 'RMG-344’ } \\
\text { Control }\end{array}$ & $\begin{array}{c}\text { 'RMG-344' } \\
\text { Treated }\end{array}$ & $\%$ Change \\
\hline \multirow{5}{*}{$\mathrm{T}_{0}$} & 0 & $12.39 \pm 0.95$ & $13.05 \pm 1.32$ & 5.06 \\
\hline & 4 & $12.98 \pm 1.21$ & $13.56 \pm 0.50$ & 4.28 \\
\hline & 24 & $13.40 \pm 0.32$ & $14.03 \pm 0.35$ & 4.49 \\
\hline & 72 & $13.73 \pm 0.04$ & $14.26 \pm 0.09$ & 3.72 \\
\hline & 144 & $11.90 \pm 0.48$ & $15.36 \pm 0.07$ & 22.53 \\
\hline \multirow{5}{*}{$\mathrm{T}_{-01}$} & 0 & $12.39 \pm 0.95$ & $12.97 \pm 0.60$ & 4.47 \\
\hline & 4 & $12.98 \pm 1.21$ & $14.09 \pm 0.50$ & 7.88 \\
\hline & 24 & $13.40 \pm 0.32$ & $14.07 \pm 0.35$ & 4.76 \\
\hline & 72 & $13.73 \pm 0.04$ & $14.26 \pm 0.09$ & 3.72 \\
\hline & 144 & $11.90 \pm 0.48$ & $13.10 \pm 0.75$ & 9.16 \\
\hline \multirow{5}{*}{$\mathrm{T}_{02}$} & 0 & $12.39 \pm 0.95$ & $13.36 \pm 0.98$ & 7.26 \\
\hline & 4 & $12.98 \pm 1.21$ & $13.41 \pm 0.90$ & 3.21 \\
\hline & 24 & $13.40 \pm 0.32$ & $14.36 \pm 0.58$ & 6.69 \\
\hline & 72 & $13.73 \pm 0.04$ & $14.79 \pm 0.14$ & 7.17 \\
\hline & 144 & $11.90 \pm 0.48$ & $12.77 \pm 0.83$ & 6.81 \\
\hline \multirow{5}{*}{$\mathrm{T}_{1}$} & 0 & $12.39 \pm 0.95$ & $14.07 \pm 1.33$ & 11.94 \\
\hline & 4 & $12.98 \pm 1.21$ & $13.34 \pm 0.90$ & 2.70 \\
\hline & 24 & $13.40 \pm 0.32$ & $14.44 \pm 0.23$ & 7.20 \\
\hline & 72 & $13.73 \pm 0.04$ & $14.92 \pm 0.65$ & 7.98 \\
\hline & 144 & $11.90 \pm 0.48$ & $13.07 \pm 0.70$ & 8.95 \\
\hline
\end{tabular}


80

Tab. 5. Quantitative changes in PAL activity in control and chemically treated plants of Vigna radiata var. 'RMG-344' for P Series

\begin{tabular}{|c|c|c|c|c|}
\hline & \multirow[b]{2}{*}{$\begin{array}{l}\text { Hours after } \\
\text { inoculation }\end{array}$} & \multicolumn{3}{|c|}{ PAL Activity ( $\mu$ kat/g fw) } \\
\hline & & $\begin{array}{c}\text { 'RMG-344' } \\
\text { Control }\end{array}$ & $\begin{array}{c}\text { 'RMG-344' } \\
\text { Treated }\end{array}$ & $\%$ Change \\
\hline \multirow{5}{*}{$\mathrm{P}_{0}$} & 0 & $0.08 \pm 0.01$ & $0.12 \pm 0.02$ & 33.33 \\
\hline & 4 & $0.13 \pm 0.00$ & $0.14 \pm 0.00$ & 7.14 \\
\hline & 24 & $0.24 \pm 0.01$ & $0.31 \pm 0.01$ & 22.58 \\
\hline & 72 & $0.26 \pm 0.01$ & $0.28 \pm 0.00$ & 7.14 \\
\hline & 144 & $0.11 \pm 0.02$ & $0.13 \pm 0.01$ & 15.38 \\
\hline \multirow{5}{*}{$P_{1}$} & 0 & $0.08 \pm 0.01$ & $0.11 \pm 0.02$ & 27.27 \\
\hline & 4 & $0.13 \pm 0.00$ & $0.15 \pm 0.01$ & 13.33 \\
\hline & 24 & $0.24 \pm 0.01$ & $0.25 \pm 0.00$ & 4.17 \\
\hline & 72 & $0.26 \pm 0.01$ & $0.33 \pm 0.04$ & 21.21 \\
\hline & 144 & $0.11 \pm 0.02$ & $0.12 \pm 0.02$ & 8.33 \\
\hline \multirow{5}{*}{$\mathrm{P}_{2}$} & 0 & $0.08 \pm 0.01$ & $0.09 \pm 0.01$ & 11.11 \\
\hline & 4 & $0.13 \pm 0.00$ & $0.15 \pm 0.00$ & 13.33 \\
\hline & 24 & $0.24 \pm 0.01$ & $0.25 \pm 0.01$ & 4.00 \\
\hline & 72 & $0.26 \pm 0.01$ & $0.34 \pm 0.06$ & 23.53 \\
\hline & 144 & $0.11 \pm 0.02$ & $0.20 \pm 0.02$ & 45.00 \\
\hline \multirow{5}{*}{$\mathrm{P}_{3}$} & 0 & $0.08 \pm 0.01$ & $0.09 \pm 0.02$ & 11.11 \\
\hline & 4 & $0.13 \pm 0.00$ & $0.15 \pm 0.00$ & 13.33 \\
\hline & 24 & $0.24 \pm 0.01$ & $0.30 \pm 0.01$ & 4.00 \\
\hline & 72 & $0.26 \pm 0.01$ & $0.27 \pm 0.01$ & 23.53 \\
\hline & 144 & $0.11 \pm 0.02$ & $0.12 \pm 0.02$ & 45.00 \\
\hline \multirow{5}{*}{$\mathrm{P}_{4}$} & 0 & $0.08 \pm 0.01$ & $0.11 \pm 0.01$ & 11.11 \\
\hline & 4 & $0.13 \pm 0.00$ & $0.16 \pm 0.00$ & 13.33 \\
\hline & 24 & $0.24 \pm 0.01$ & $0.26 \pm 0.01$ & 20.00 \\
\hline & 72 & $0.26 \pm 0.01$ & $0.32 \pm 0.02$ & 3.70 \\
\hline & 144 & $0.11 \pm 0.02$ & $0.13 \pm 0.02$ & 8.33 \\
\hline \multirow{5}{*}{$\mathrm{P}_{6}$} & 0 & $0.08 \pm 0.01$ & $0.11 \pm 0.01$ & 18.75 \\
\hline & 4 & $0.13 \pm 0.00$ & $0.16 \pm 0.00$ & 18.75 \\
\hline & 24 & $0.24 \pm 0.01$ & $0.25 \pm 0.01$ & 4.00 \\
\hline & 72 & $0.26 \pm 0.01$ & $0.28 \pm 0.01$ & 7.14 \\
\hline & 144 & $0.11 \pm 0.02$ & $0.14 \pm 0.02$ & 21.43 \\
\hline \multirow{5}{*}{$\mathrm{P}_{7}$} & 0 & $0.08 \pm 0.01$ & $0.10 \pm 0.02$ & 20.00 \\
\hline & 4 & $0.13 \pm 0.00$ & $0.16 \pm 0.00$ & 18.75 \\
\hline & 24 & $0.24 \pm 0.01$ & $0.29 \pm 0.00$ & 17.24 \\
\hline & 72 & $0.26 \pm 0.01$ & $0.27 \pm 0.01$ & 13.70 \\
\hline & 144 & $0.11 \pm 0.02$ & $0.17 \pm 0.02$ & 35.29 \\
\hline
\end{tabular}

The enhancement in PAL activity levels observed may either be due to induction of enzyme or conversion of an inactive form to active form. The observations conform to those of Jones (1984) who reported a stimulated metabolism of phenolic compounds in plants upon infection along with an increase in activity of related enzyme. In the present study also the maximum PAL activity is obtained before the maximum synthesis of phenols and flavonoids in both the series of compounds for mung plants.
Tab. 6. Quantitative changes in PAL activity in control and chemically treated plants of Vigna radiata var. 'RMG-344' for T Series

\begin{tabular}{|c|c|c|c|c|}
\hline & \multirow[b]{2}{*}{$\begin{array}{l}\text { Hours after } \\
\text { inoculation }\end{array}$} & \multicolumn{3}{|c|}{ PAL Activity ( $\mu \mathrm{kat} / \mathrm{g} \mathrm{fw})$} \\
\hline & & $\begin{array}{c}\text { 'RMG-344' } \\
\text { Control }\end{array}$ & $\begin{array}{c}\text { 'RMG-344' } \\
\text { Treated }\end{array}$ & $\begin{array}{c}\% \\
\text { Change }\end{array}$ \\
\hline \multirow{5}{*}{$\mathrm{T}_{0}$} & 0 & $0.08 \pm 0.01$ & $0.10 \pm 0.02$ & 20.00 \\
\hline & 4 & $0.13 \pm 0.00$ & $0.16 \pm 0.00$ & 18.75 \\
\hline & 24 & $0.24 \pm 0.01$ & $0.31 \pm 0.02$ & 22.58 \\
\hline & 72 & $0.26 \pm 0.01$ & $0.28 \pm 0.00$ & 7.14 \\
\hline & 144 & $0.11 \pm 0.02$ & $0.13 \pm 0.02$ & 15.39 \\
\hline \multirow{5}{*}{$\mathrm{T}_{-01}$} & 0 & $0.08 \pm 0.01$ & $0.10 \pm 0.01$ & 20.00 \\
\hline & 4 & $0.13 \pm 0.00$ & $0.15 \pm 0.00$ & 13.33 \\
\hline & 24 & $0.24 \pm 0.01$ & $0.35 \pm 0.01$ & 31.43 \\
\hline & 72 & $0.26 \pm 0.01$ & $0.26 \pm 0.02$ & 0.00 \\
\hline & 144 & $0.11 \pm 0.02$ & $0.14 \pm 0.02$ & 21.43 \\
\hline \multirow{5}{*}{$\mathrm{T}_{-02}$} & 0 & $0.08 \pm 0.01$ & $0.11 \pm 0.01$ & 27.27 \\
\hline & 4 & $0.13 \pm 0.00$ & $0.17 \pm 0.01$ & 23.53 \\
\hline & 24 & $0.24 \pm 0.01$ & $0.32 \pm 0.00$ & 25.00 \\
\hline & 72 & $0.26 \pm 0.01$ & $0.28 \pm 0.01$ & 7.14 \\
\hline & 144 & $0.11 \pm 0.02$ & $0.13 \pm 0.01$ & 15.39 \\
\hline \multirow{5}{*}{$\mathrm{T}_{1}$} & 0 & $0.08 \pm 0.01$ & $0.11 \pm 0.00$ & 27.27 \\
\hline & 4 & $0.13 \pm 0.00$ & $0.17 \pm 0.00$ & 23.53 \\
\hline & 24 & $0.24 \pm 0.01$ & $0.34 \pm 0.03$ & 29.41 \\
\hline & 72 & $0.26 \pm 0.01$ & $0.29 \pm 0.02$ & 10.34 \\
\hline & 144 & $0.11 \pm 0.02$ & $0.12 \pm 0.01$ & 8.33 \\
\hline
\end{tabular}

\section{Peroxidase}

The peroxidase activity was determined in two plants Vigna radiata var. 'RMG-344' at different time intervals after chemical application using Guaiacol as substrate.

From the data the maximum activity was obtained in Vigna radiata for $\mathrm{P}_{2}$ in $\mathrm{P}$ series and for $\mathrm{T}_{0}$ in $\mathrm{T}$ series at 72 hours whereas the maximum percent change was obtained in $\mathrm{P}$ series for $\mathrm{P}_{3}$ and for $\mathrm{T}_{0}$ in $\mathrm{T}$ series at 24 hours. T Series showed highest peroxidase activity as compared to $P$ series (Tab. 7 and 8)

In general, there was increase in peroxidase activity in chemically treated plants than control plants which show induction of peroxidase which is considered one of the PR proteins. This is an agreement to the results of Ye et al. (1990) and Hammershmidt (1982). The changes in the level of total phenols and specific activities of polyphenoloxidase, peroxidase and catalase were determined in healthy and Alternaria alternata leaf blight susceptible leaves of Brassica species. The specific activity of polyphenol oxidase remained higher while that of peroxidase remained lower in tolerant species.

Histochemical Detection of Hydrogen Peroxide by DAB

The presence of $\mathrm{H}_{2} \mathrm{O}_{2}$ was also detected histochemically in control and pathogen inoculated leaves of moth bean plants using 3, 3-diaminobenzidine (DAB). Active oxygen species (AOS) play an important role in plants in general and in plant-pathogen interactions (Lamb and Dixon, 1997). DAB polymerizes instantly and locally as soon as it 
Tab. 7. Quantitative changes in Peroxidase activity in control and chemically treated plants of Vigna radiata var. 'RMG-344' for P Series

\begin{tabular}{|c|c|c|c|c|}
\hline & \multirow{2}{*}{$\begin{array}{l}\text { Hours after } \\
\text { inoculation }\end{array}$} & \multicolumn{3}{|c|}{ Peroxidase Activity (units/g fw) } \\
\hline & & $\begin{array}{c}\text { 'RMG-344' } \\
\text { Control }\end{array}$ & $\begin{array}{c}\text { 'RMG-344' } \\
\text { Treated }\end{array}$ & $\begin{array}{c}\% \\
\text { Change }\end{array}$ \\
\hline \multirow{5}{*}{$\mathrm{P}_{0}$} & 0 & $0.13 \pm 0.01$ & $0.16 \pm 0.01$ & 18.75 \\
\hline & 4 & $0.10 \pm 0.01$ & $0.11 \pm 0.00$ & 9.09 \\
\hline & 24 & $0.17 \pm 0.01$ & $0.20 \pm 0.03$ & 15.00 \\
\hline & 72 & $0.21 \pm 0.00$ & $0.24 \pm 0.04$ & 12.50 \\
\hline & 144 & $0.12 \pm 0.00$ & $0.13 \pm 0.03$ & 7.69 \\
\hline \multirow{5}{*}{$\mathrm{P}_{1}$} & 0 & $0.13 \pm 0.01$ & $0.15 \pm 0.02$ & 13.33 \\
\hline & 4 & $0.10 \pm 0.01$ & $0.12 \pm 0.00$ & 16.67 \\
\hline & 24 & $0.17 \pm 0.01$ & $0.23 \pm 0.02$ & 26.09 \\
\hline & 72 & $0.21 \pm 0.00$ & $0.25 \pm 0.00$ & 16.00 \\
\hline & 144 & $0.12 \pm 0.00$ & $0.15 \pm 0.02$ & 20.00 \\
\hline \multirow{5}{*}{$\mathrm{P}_{2}$} & 0 & $0.13 \pm 0.01$ & $0.16 \pm 0.02$ & 18.75 \\
\hline & 4 & $0.10 \pm 0.01$ & $0.12 \pm 0.01$ & 16.67 \\
\hline & 24 & $0.17 \pm 0.01$ & $0.27 \pm 0.03$ & 37.04 \\
\hline & 72 & $0.21 \pm 0.00$ & $0.30 \pm 0.00$ & 30.00 \\
\hline & 144 & $0.12 \pm 0.00$ & $0.14 \pm 0.01$ & 14.29 \\
\hline \multirow{5}{*}{$\mathrm{P}_{3}$} & 0 & $0.13 \pm 0.01$ & $0.15 \pm 0.02$ & 13.33 \\
\hline & 4 & $0.10 \pm 0.01$ & $0.11 \pm 0.01$ & 9.09 \\
\hline & 24 & $0.17 \pm 0.01$ & $0.28 \pm 0.03$ & 39.29 \\
\hline & 72 & $0.21 \pm 0.00$ & $0.26 \pm 0.03$ & 25.00 \\
\hline & 144 & $0.12 \pm 0.00$ & $0.15 \pm 0.02$ & 20.00 \\
\hline \multirow{5}{*}{$\mathrm{P}_{4}$} & 0 & $0.13 \pm 0.01$ & $0.16 \pm 0.01$ & 18.75 \\
\hline & 4 & $0.10 \pm 0.01$ & $0.12 \pm 0.00$ & 16.67 \\
\hline & 24 & $0.17 \pm 0.01$ & $0.22 \pm 0.03$ & 22.73 \\
\hline & 72 & $0.21 \pm 0.00$ & $0.24 \pm 0.02$ & 12.50 \\
\hline & 144 & $0.12 \pm 0.00$ & $0.13 \pm 0.01$ & 7.69 \\
\hline \multirow{5}{*}{$\mathrm{P}_{6}$} & 0 & $0.13 \pm 0.01$ & $0.14 \pm 0.03$ & 7.14 \\
\hline & 4 & $0.10 \pm 0.01$ & $0.12 \pm 0.01$ & 16.67 \\
\hline & 24 & $0.17 \pm 0.01$ & $0.25 \pm 0.04$ & 32.00 \\
\hline & 72 & $0.21 \pm 0.00$ & $0.27 \pm 0.03$ & 22.22 \\
\hline & 144 & $0.12 \pm 0.00$ & $0.15 \pm 0.00$ & 20.00 \\
\hline \multirow{5}{*}{$\mathrm{P}_{7}$} & 0 & $0.13 \pm 0.01$ & $0.15 \pm 0.02$ & 13.33 \\
\hline & 4 & $0.10 \pm 0.01$ & $0.12 \pm 0.01$ & 16.67 \\
\hline & 24 & $0.17 \pm 0.01$ & $0.21 \pm 0.04$ & 19.05 \\
\hline & 72 & $0.21 \pm 0.00$ & $0.24 \pm 0.02$ & 12.50 \\
\hline & 144 & $0.12 \pm 0.00$ & $0.15 \pm 0.02$ & 20.00 \\
\hline
\end{tabular}

comes in contact with $\mathrm{H}_{2} \mathrm{O}_{2}$ in the presence of peroxidase and by allowing the leaf to take up this substrate, in vivo and in-situ detection of $\mathrm{H}_{2} \mathrm{O}_{2}$ can be done at subcellular levels (Thordal-Christensen et al., 1997).

DAB is readily taken up from the chemical treated site and distributed in whole the leaf. As a positive control for uptake and reactivity of $\mathrm{DAB}, \mathrm{H}_{2} \mathrm{O}_{2}$ produced in the vascular tissue detected as a strong reddish-brown co lour visible to the naked eye within 3-5 hours. Use of the DAB-
Tab. 8. Quantitative changes in Peroxidase activity in control and chemically treated plants of Vigna radiata var. 'RMG-344' for T Series

\begin{tabular}{|c|c|c|c|c|}
\hline & \multirow{2}{*}{$\begin{array}{l}\text { Hours after } \\
\text { inoculation }\end{array}$} & \multicolumn{3}{|c|}{ Peroxidase Activity (units/g fw) } \\
\hline & & $\begin{array}{c}\text { 'RMG-344' } \\
\text { Control }\end{array}$ & $\begin{array}{c}\text { 'RMG-344' } \\
\text { Treated }\end{array}$ & $\begin{array}{c}\% \\
\text { Change }\end{array}$ \\
\hline \multirow{5}{*}{$\mathrm{T}_{0}$} & 0 & $0.13 \pm 0.01$ & $0.15 \pm 0.02$ & 13.33 \\
\hline & 4 & $0.10 \pm 0.01$ & $0.11 \pm 0.01$ & 9.09 \\
\hline & 24 & $0.17 \pm 0.01$ & $0.30 \pm 0.00$ & 43.33 \\
\hline & 72 & $0.21 \pm 0.00$ & $0.33 \pm 0.04$ & 36.36 \\
\hline & 144 & $0.12 \pm 0.00$ & $0.15 \pm 0.01$ & 20.00 \\
\hline \multirow{5}{*}{$\mathrm{T}_{-01}$} & 0 & $0.13 \pm 0.01$ & $0.17 \pm 0.00$ & 23.53 \\
\hline & 4 & $0.10 \pm 0.01$ & $0.13 \pm 0.00$ & 23.08 \\
\hline & 24 & $0.17 \pm 0.01$ & $0.28 \pm 0.03$ & 39.29 \\
\hline & 72 & $0.21 \pm 0.00$ & $0.30 \pm 0.00$ & 30.00 \\
\hline & 144 & $0.12 \pm 0.00$ & $0.14 \pm 0.01$ & 14.29 \\
\hline \multirow{5}{*}{$\mathrm{T}_{-02}$} & 0 & $0.13 \pm 0.01$ & $0.15 \pm 0.00$ & 13.33 \\
\hline & 4 & $0.10 \pm 0.01$ & $0.13 \pm 0.01$ & 23.08 \\
\hline & 24 & $0.17 \pm 0.01$ & $0.27 \pm 0.03$ & 37.04 \\
\hline & 72 & $0.21 \pm 0.00$ & $0.28 \pm 0.03$ & 25.00 \\
\hline & 144 & $0.12 \pm 0.00$ & $0.13 \pm 0.01$ & 7.69 \\
\hline \multirow{5}{*}{$\mathrm{T}_{1}$} & 0 & $0.13 \pm 0.01$ & $0.14 \pm 0.02$ & 7.14 \\
\hline & 4 & $0.10 \pm 0.01$ & $0.14 \pm 0.00$ & 28.57 \\
\hline & 24 & $0.17 \pm 0.01$ & $0.28 \pm 0.03$ & 39.29 \\
\hline & 72 & $0.21 \pm 0.00$ & $0.30 \pm 0.00$ & 30.00 \\
\hline & 144 & $0.12 \pm 0.00$ & $0.17 \pm 0.00$ & 23.53 \\
\hline
\end{tabular}

uptake method for studying $\mathrm{H}_{2} \mathrm{O}_{2}$ requires the presence of endogenous peroxidase activity in order to ensure the formation of a visible polymer. A simple test for required peroxidase activity involves exposure of the target tissue to $\mathrm{DAB}$ and $\mathrm{H}_{2} \mathrm{O}_{2}$ In the present study redish brown patches can be seen in the chemically treated plants which are due to the localized accumulation of $\mathrm{H}_{2} \mathrm{O}_{2}$ (Fig. 1 and 2).

A distinct colouration in the inoculated leaves as compared to the control leaves evidences that $\mathrm{H}_{2} \mathrm{O}_{2}$ accumulation is more in the chemically treated plants compared to the control plants. DAB is taken up by living plant tissue where it polymerizes instantly and locally at sites of peroxidase activity into a reddish-brown polymer. Similar

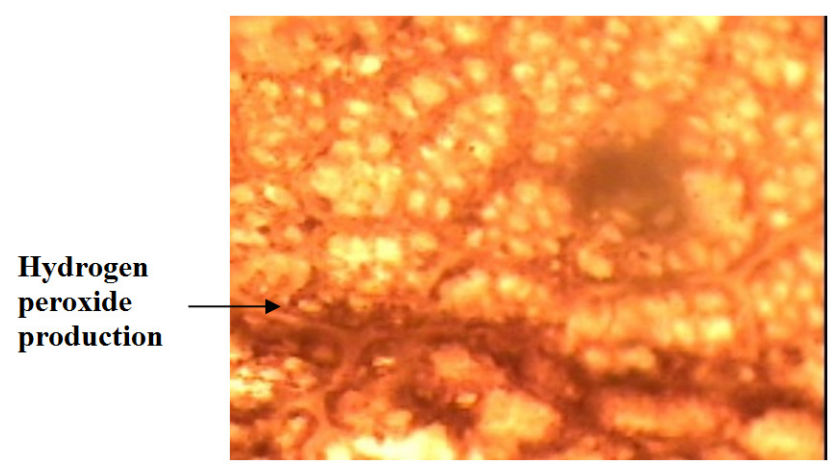

Fig. 1. Whole mount of leaves of vigna radiata showing the production of $\mathrm{H}_{2} \mathrm{O}_{2}$ by DAB method 
82

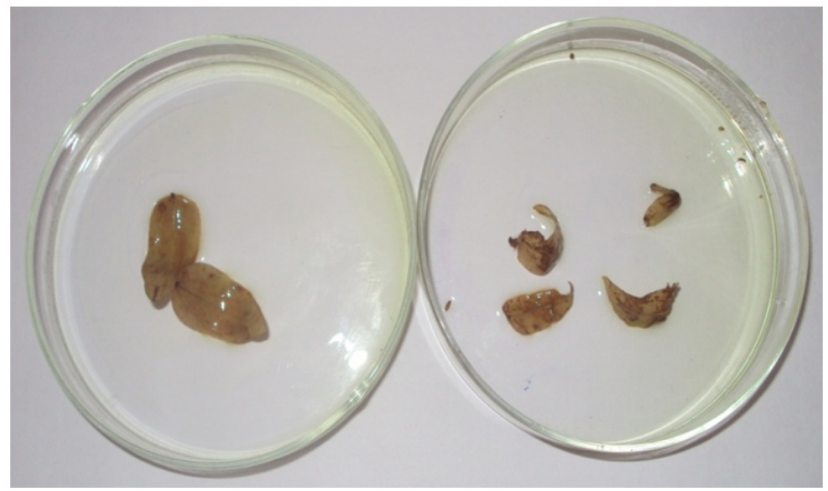

Fig. 2. Histochemical detection of hydrogen peroxide using $\mathrm{DAB}$ in Vigna radiata

Tab. 9. Quantitative changes in Total Protein content in control and chemically treated plants of Vigna radiata var. 'RMG-344' for P Series

\begin{tabular}{|c|c|c|c|c|}
\hline & \multirow{2}{*}{$\begin{array}{l}\text { Hours after } \\
\text { inoculation }\end{array}$} & \multicolumn{3}{|c|}{ Total protein $(\mathrm{mg} / \mathrm{g} \mathrm{fw})$} \\
\hline & & $\begin{array}{c}\text { 'RMG-344' } \\
\text { Control }\end{array}$ & $\begin{array}{c}\text { 'RMG-344' } \\
\text { Treated }\end{array}$ & $\begin{array}{c}\% \\
\text { Change }\end{array}$ \\
\hline \multirow{5}{*}{$\mathrm{P}_{0}$} & 0 & $9.93 \pm 0.37$ & $10.08 \pm 0.54$ & 1.49 \\
\hline & 4 & $11.34 \pm 0.47$ & $11.80 \pm 0.54$ & 3.90 \\
\hline & 24 & $11.10 \pm 0.15$ & $11.17 \pm 0.68$ & 0.63 \\
\hline & 72 & $11.34 \pm 0.08$ & $12.02 \pm 0.16$ & 5.66 \\
\hline & 144 & $4.16 \pm 0.17$ & $5.87 \pm 0.11$ & 29.13 \\
\hline \multirow{5}{*}{$\mathrm{P}_{1}$} & 0 & $9.93 \pm 0.37$ & $10.08 \pm 0.30$ & 1.49 \\
\hline & 4 & $11.34 \pm 0.47$ & $11.79 \pm 0.46$ & 3.82 \\
\hline & 24 & $11.10 \pm 0.15$ & $11.76 \pm 0.28$ & 5.61 \\
\hline & 72 & $11.34 \pm 0.08$ & $11.93 \pm 0.19$ & 4.95 \\
\hline & 144 & $4.16 \pm 0.17$ & $6.27 \pm 0.22$ & 33.65 \\
\hline \multirow{5}{*}{$\mathrm{P}_{2}$} & 0 & $9.93 \pm 0.37$ & $10.08 \pm 0.53$ & 1.49 \\
\hline & 4 & $11.34 \pm 0.47$ & $12.93 \pm 0.25$ & 12.30 \\
\hline & 24 & $11.10 \pm 0.15$ & $11.79 \pm 0.11$ & 5.85 \\
\hline & 72 & $11.34 \pm 0.08$ & $12.23 \pm 0.26$ & 72.77 \\
\hline & 144 & $4.16 \pm 0.17$ & $6.27 \pm 0.22$ & 33.65 \\
\hline \multirow{5}{*}{$\mathrm{P}_{3}$} & 0 & $9.93 \pm 0.37$ & $10.09 \pm 0.28$ & 4.59 \\
\hline & 4 & $11.34 \pm 0.47$ & $11.61 \pm 0.55$ & 2.33 \\
\hline & 24 & $11.10 \pm 0.15$ & $12.31 \pm 0.03$ & 9.83 \\
\hline & 72 & $11.34 \pm 0.08$ & $11.42 \pm 0.94$ & 0.53 \\
\hline & 144 & $4.16 \pm 0.17$ & $4.55 \pm 0.47$ & 8.57 \\
\hline \multirow{5}{*}{$\mathrm{P}_{4}$} & 0 & $9.93 \pm 0.37$ & $10.74 \pm 0.14$ & 7.54 \\
\hline & 4 & $11.34 \pm 0.47$ & $12.49 \pm 0.30$ & 9.21 \\
\hline & 24 & $11.10 \pm 0.15$ & $14.10 \pm 0.35$ & 21.28 \\
\hline & 72 & $11.34 \pm 0.08$ & $12.52 \pm 0.21$ & 9.43 \\
\hline & 144 & $4.16 \pm 0.17$ & $5.43 \pm 0.22$ & 23.39 \\
\hline \multirow{5}{*}{$\mathrm{P}_{6}$} & 0 & $9.93 \pm 0.37$ & $10.85 \pm 0.27$ & 8.48 \\
\hline & 4 & $11.34 \pm 0.47$ & $11.96 \pm 0.35$ & 5.18 \\
\hline & 24 & $11.10 \pm 0.15$ & $11.13 \pm 0.09$ & 0.27 \\
\hline & 72 & $11.34 \pm 0.08$ & $12.14 \pm 0.57$ & 6.59 \\
\hline & 144 & $4.16 \pm 0.17$ & $4.93 \pm 0.19$ & 15.62 \\
\hline \multirow{5}{*}{$\mathrm{P}_{7}$} & 0 & $9.93 \pm 0.37$ & $10.89 \pm 0.32$ & 8.82 \\
\hline & 4 & $11.34 \pm 0.47$ & $12.13 \pm 0.32$ & 6.51 \\
\hline & 24 & $11.10 \pm 0.15$ & $12.51 \pm 0.52$ & 11.27 \\
\hline & 72 & $11.34 \pm 0.08$ & $13.63 \pm 0.32$ & 16.80 \\
\hline & 144 & $4.16 \pm 0.17$ & $5.84 \pm 0.81$ & 28.77 \\
\hline
\end{tabular}

detection of superoxide and $\mathrm{H}_{2} \mathrm{O}_{2}$ was demonstrated by Yang et al. (2005) in transgenic rice plants upon infection with avirulent and virulent strains of the blast fungus. The highly localized accumulation of $\mathrm{H}_{2} \mathrm{O}_{2}$ is consistent with its direct role as an antimicrobial agent and as the cause of localized membrane damage at sites of bacterial (Pseudomonas syringae pv. phaseolicola) attachment in lettuce plants (Bestwick et al., 1997).

\section{Total Protein}

The total protein content was determined by Lowry's method using BSA as standard. From Tab. 9 and 10 and Fig. 3 and 4, it is clear that the maximum protein content was obtained for $\mathrm{P}_{4}$ in $\mathrm{P}$ series at 24 hours and for $\mathrm{T}_{0}$ in $\mathrm{T}$ series at 24 hours, whereas the maximum \% change was found for $\mathrm{P}_{1}$ and $\mathrm{P}_{2}$ at 144 hours in $\mathrm{P}$ series and in T series for $\mathrm{T}_{01}$ at 72 hours in Vigna radiate. The total protein content for Vigna radiata was higher in $\mathrm{P}$ series as compared to $T$ series (Tab. 9 and 10 ).

The increase in protein content may be because of increase in PR protein after infection with pathogen (Bailey and Mansfield, 1992; Ebel, 1986). Induction of PR proteins following elicitor treatment, wounding or tissue infection is accompanied by a massive alteration in the pattern of gene expression and activation of other defense responses such as phytoalexin accumulation, lignin deposition and synthesis of cell wall hydroxyproline rich glycoproteins (Cramer et al., 1985; Lawton and Lamb, 1987).

Tab. 10. Quantitative changes in Total Protein content in control and chemically treated plants of Vigna radiata var. 'RMG-344' for T Series

\begin{tabular}{|c|c|c|c|c|}
\hline & \multirow{2}{*}{$\begin{array}{l}\text { Hours after } \\
\text { inoculation }\end{array}$} & \multicolumn{3}{|c|}{ Total protein $(\mathrm{mg} / \mathrm{g} \mathrm{fw})$} \\
\hline & & $\begin{array}{c}\text { 'RMG-344' } \\
\text { Control }\end{array}$ & $\begin{array}{c}\text { 'RMG-344' } \\
\text { Treated }\end{array}$ & $\begin{array}{c}\% \\
\text { Change }\end{array}$ \\
\hline \multirow{5}{*}{$\mathrm{T}_{0}$} & 0 & $6.86 \pm 0.83$ & $7.79 \pm 0.25$ & 11.94 \\
\hline & 4 & $7.86 \pm 0.21$ & $8.16 \pm 0.26$ & 3.68 \\
\hline & 24 & $9.09 \pm 0.09$ & $12.10 \pm 0.10$ & 24.88 \\
\hline & 72 & $6.83 \pm 0.25$ & $9.97 \pm 0.32$ & 31.49 \\
\hline & 144 & $5.76 \pm 0.33$ & $7.97 \pm 0.10$ & 27.73 \\
\hline \multirow{5}{*}{$\mathrm{T}_{01}$} & 0 & $6.86 \pm 0.83$ & $9.74 \pm 0.34$ & 26.08 \\
\hline & 4 & $7.86 \pm 0.21$ & $8.34 \pm 0.24$ & 5.76 \\
\hline & 24 & $9.09 \pm 0.09$ & $10.59 \pm 0.69$ & 14.16 \\
\hline & 72 & $6.83 \pm 0.25$ & $12.05 \pm 0.03$ & 43.32 \\
\hline & 144 & $5.76 \pm 0.33$ & $6.70 \pm 0.14$ & 14.03 \\
\hline \multirow{5}{*}{$\mathrm{T}_{02}$} & 0 & $6.86 \pm 0.83$ & $7.65 \pm 0.51$ & 10.33 \\
\hline & 4 & $7.86 \pm 0.21$ & $8.26 \pm 0.09$ & 4.84 \\
\hline & 24 & $9.09 \pm 0.09$ & $9.72 \pm 0.27$ & 6.48 \\
\hline & 72 & $6.83 \pm 0.25$ & $10.48 \pm 0.34$ & 34.83 \\
\hline & 144 & $5.76 \pm 0.33$ & $6.16 \pm 0.13$ & 6.49 \\
\hline \multirow{5}{*}{$\mathrm{T}_{1}$} & 0 & $6.86 \pm 0.83$ & $7.38 \pm 0.66$ & 7.05 \\
\hline & 4 & $7.86 \pm 0.21$ & $8.13 \pm 0.23$ & 3.32 \\
\hline & 24 & $9.09 \pm 0.09$ & $9.96 \pm 0.28$ & 8.74 \\
\hline & 72 & $6.83 \pm 0.25$ & $11.14 \pm 0.17$ & 38.69 \\
\hline & 144 & $5.76 \pm 0.33$ & $7.63 \pm 0.05$ & 24.51 \\
\hline
\end{tabular}


RMG-344 Control and Chemically Treated (P Series)

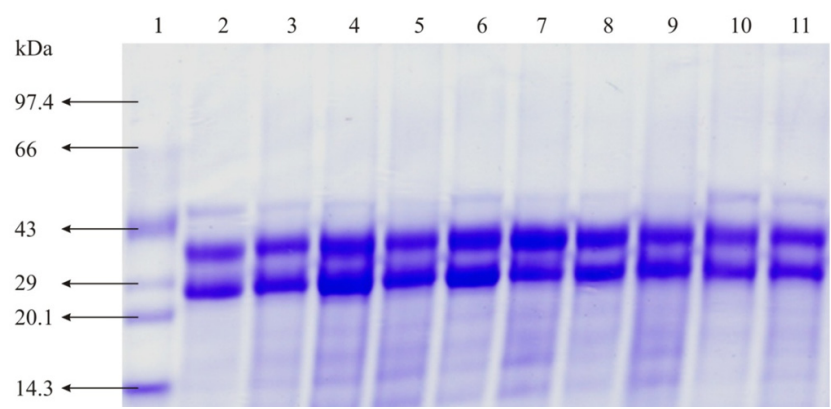

Fig. 3. SDS-PAGE of total proteins of 24 hours control and chemically treated samples of Vigna radiata plants var. 'RMG$344^{\prime}$ (P Series)

Lane 01: High Range Molecular weight Protein Marker; Lane 02: 'RMG-344' Control, 0 hour; Lane 03: 'RMG-344' chemically treated, 0 hour; Lane 04: 'RMG-344' Control, 24 hours; Lane 05: 'RMG-344' chemically treated, $P_{0}, 24$ hours; Lane 06: 'RMG-344' chemically treated, $P_{1}, 24$ hours; Lane 07: 'RMG344 ' chemically treated, $\mathrm{P}_{2}, 24$ hours; Lane 08: 'RMG-344' chemically treated, $\mathrm{P}_{3}, 24$ hours; Lane 09: 'RMG-344' chemically treated, $\mathrm{P}_{4}, 24$ hours; Lane 10: 'RMG-344' chemically treated, $\mathrm{P}_{6}, 24$ hours; Lane 11: 'RMG-344' chemically treated, $\mathrm{P}_{7}, 24$ hours

\section{RMG-344 Control and Chemically Treated (T Series)}

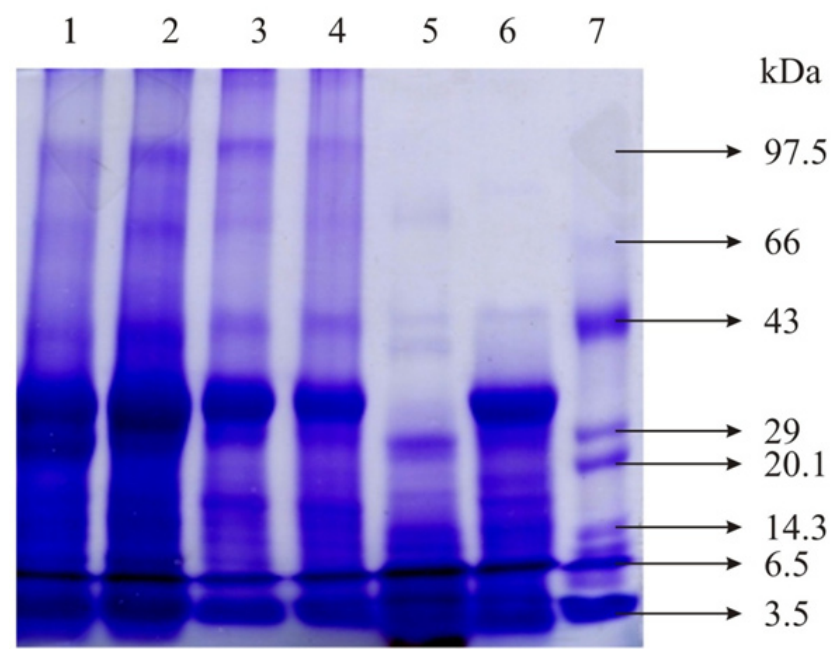

Fig. 4. SDS-PAGE of total protein of control and chemically treated Vigna radiata var. 'RMG-344' for T Series

Lane 1: Control, 0 hour; Lane 2: Control, 24 hours; Lane 3: chemically treated, $\mathrm{T}_{0}, 24$ hours; Lane 4: chemically treated, $\mathrm{T}_{-01}, 24$ hours; Lane 5: chemically treated, $\mathrm{T}_{02}, 24$ hours; Lane 6: chemically treated, $T_{1}, 24$ hours; Lane 7: High Range Molecular weight Protein Marker

\section{SDS-PAGE}

The total proteins of control and treated samples were also characterized by SDS-PAGE in 10\% resolving gel. The protein profile obtained clearly showed resolved band patterns with increased intensity in treated samples. The pro- tein profile of the total proteins revealed the presence of a number of bands in the range of $97.4 \mathrm{kDa}-3.5 \mathrm{kDa}$. This is in agreement with Kombrink et al. (1998) who proved that gene for PR-proteins are induced by elicitation that imparts resistance to the plants. High range molecular weight protein markers were also run to correlated with molecular weight of various proteins.

On comparing the bands with molecular weight the two plants of $V$. radiata var. 'RMG-344' showed various bands for both series. For P series, Vigna radiata var. 'RMG-344' showed different major bands of $\sim 50 \mathrm{kDa}$, $\sim 40 \mathrm{kDa}, \sim 29 \mathrm{kDa}$ and $\sim 16 \mathrm{kDa}$ to be present in both control and chemically treated plants samples in 0 and 24 hours (Fig. 3).

For $\mathrm{T}$ series various bands are obtained in chemically treated plants samples. Bands of $\sim 3.5 \mathrm{kDa}, \sim 6.5 \mathrm{kDa}$, $\sim 14.3 \mathrm{kDa}, \sim 29 \mathrm{kDa}, \sim 43 \mathrm{kDa}$ and $\sim 97.4 \mathrm{kDa}$ were found to be present in almost all the samples of control and chemically treated samples of 0 hour and 24 hours (Fig. 4).

These results can be compared to those reported by Van Loon and Van Strien (1999) who reported that PR protein preparation contain varying amounts of proteins extracted from different plants.

\section{Antifungal activity}

For the antifungal activity detection five fungus were used, Fusarium oxysporum, Macrophomina phaseolina, Alternaria brassicicola, Trichoderma viridae and Aspergillus niger. In which only Fusarium oxysporum, Aspergillus niger showed antifungal activity or zone of inhibition against the two series of chemicals. Aspergillus niger showed the largest zone of inhibition against the $\mathrm{P}_{0}$ in $\mathrm{P}$ Series. Whereas for Fusarium oxysporum the largest zone of inhibition of $30 \mathrm{~mm}$ was observed for $\mathrm{P}_{7}$ in $\mathrm{P}$ series. These zones were visible after 48 hours of incubation. However no zone of inhibition was observed for Macrophomina phaseolina, Alternaria brassicicola, Trichoderma viridae which are in agrrement with the findings of Galeotti et al. (2008) and Mattila and Hellstrom (2007).

\section{Conclusions}

The result of the present study revealed that plants have evolved multiple defense mechanisms against microbial pathogens and various types of environmental stress. Besides anti-microbial secondary metabolite, some of which are performed and some of which are induced by infection. In the present study the polyphenol and flavonoid content was higher in the chemically treated plants as compared to the control. Similarly $\mathrm{H}_{2} \mathrm{O}_{2}$ accumulation, PAL activity, total protein, and the protein profile obtained clearly showed resolved banding patterns with increased intensity in treated samples. Therefore, additional research in area of systemic acquired resistance (SAR) by heterocyclic compounds having azole groups for activation resistance 
84

against pest is needed in the current scenario. In the long term, it will probably be possible to generate gene cassettes for complete pathways, which could then be used for production of valuable defensive mechanism for metabolic engineering of crop plants. This will improve their resistance against microbial pathogens as well as various environmental stresses.

\section{References}

Attridge TH, Stewart GR, Smith H (1971). End-product inhibition of Pisum phenylalanineammonia-lyase by the Pisum flavonoids. FEBS Let 17:84-86.

Bailey JA, Mansfield JW (1992). Phytoalexins. Blackie and Sons Ltd., Glasgow and London, $334 \mathrm{p}$.

Bestwick CS, Brown IR, Bennett MHR, Mansfield JW (1997). Localization of hydrogen peroxide accumulation during the hypersensitive reaction of lettuce cells to Pseudomonas syringae pv pbaseolicola. Plant Cell 9:209-221.

Camm El, Towers GHN (1973). Phenylalanine ammonia-lyase. Photochem 12:961-973.

Chang C, Yang M, Ven H, Chern J (2002). Estimation of total flavonoid content in propolis by two complementary colorimetric methods. J Food Drug Analysis 10:178-182.

Cramer CL, Ryder TB, Bell JN, Lamb CJ (1985). Rapid switching of plant gene expression by fungal elicitor. Science 227:1240-1243.

Das NP, Pereira TA (1990). Effects of flavonoids on thermal autooxidation of Palm oil: structure- activity relationship. J Am Oil Chem Soc 67:255-258.

Ebel J (1986). Phytoalexin synthesis: The biochemical analysis of the induction process. Ann Rev Phytopathol 24:235-264.

Friedrich L, Lawton K, Dincher S, Winter A, Staub T, Uknes S, Kessmann H, Ryals J (1996). Benzothiadiazole induces systemic acquired resistance in tobacco. Plant J 10:61-70.

Fritig B, Heitz T, Legrand M (1998). Antimicrobial proteins in induced plant defense. Curr Opin Immunol 10:16-22.

Garlach J, Volrath S, Knauf-Beiter G, Hengy G, Beckhove U, Kogel KH, Oostendorp M, Staub T, Ward E, Kessmann H, Ryals J(1996). Benzothiadiazole, a nove1 class of inducers of systemic acquired resistance, activates gene expression and disease resistance in wheat. Plant Cell 8:629-643.

Galeotti F, Barile E, Curir P, Dolci M, Lanzotti V (2008). Flavonoids from carnation (Dianthus caryophyllus) and their antifungal activity. Phytochem Lett 1:44-48.

Hammerschmidt R, Nuckles EM, Kuc J(1982). Association of enhanced peroxidase activity with induced systemic resistance of cucumber to Colletotrichum lagenarium. Physiol Plant Pathol 20:73-82.

Huang D, Ou B, Prior RL (2005). The chemistry behind antioxidant capacity assays. J Agric Food Chem 53:18411856.

Jones DH (1984). Phenylalanine ammonia-lyase: regulation of its induction and its role in plant development. Phytochem 23:1349-1359.

Kessmann H, Staub T, Hofmann C, Maetzke T, Herzog J, Ward E, Uknes S, Ryals J (1994). Induction of systemic acquired resistance in plants by chemicals. Ann Rev Phytopathol 32:439-459.

Kombrink E, Somssich IE (1995). Defense responses of plants to pathogens. Adv Bot Res 21:1-34.

Kuc J (1982). Induced immunity to plant disease. Bioscience 32:8954-860.

Laemmli UK (1970). Cleavage of Structural Proteins during the Assembly of the Head of Bacteriophage T4. Nature 277:680-685.

Lamb C, Dixon RA (1997). The oxidative burst in plant disease resistance. Ann Rev Plant Physiol Plant Mol Biol 48:251275.

Lawton K, Friedrich L, Hunt M, Weymann K, Staub T, Kessmann H, Ryals J (1996). Benzothiadiazole induces disease resistance in Arabidopsis by activation of the systemic acquired resistance signal transduction pathway. Plant J 10:71-82.

Lawton MA, Lamb CJ (1987). Transcriptional activation of plant defense genes by fungal elicitor, wounding and infection. Mol Cell Biol 7:335-341.

Lowry OH, Rosebrough NJ, Farr AL, Randall RJ (1951). Protein measurements with the Folin Phenol reagent. J Biol Chem 193:265-275.

McDonald S, Prenzler PD, Autolovich M, Robards K (2001). Phenolic content of antioxidant activity of olives extracts. Food Chem 73:73-84.

Métraux JP, Ahl-Goy P, Staub T, Speich J, Steinemann A, Ryals J, Ward E (1991). Induced resistance in cucumber in response to 2,8 dichloroisonicotinic acid and pathogens, 432-439 p. In: Hennecke H, Verma DPS (Eds.). Advances in Molecular Genetics of Plant-Microbe Interactions, Vol. 1, Dordrecht, The Netherlands: Kluwer Academic Publishers.

Mattila P, Hellstrom J (2007). Phenolic acids in potatoes, vegetables, and some of their products. J Food Composit Analysis 20:152-160.

Neuenschwander U, Friedrich L, Delaney T, Vernooij B, Kessmann H, Ryals J (1995). Activation of plant disease resistance. Aspects Appl Biol 42:217-225.

Pearce G, Marchand PA, Griswold J, Lewis NG, Ryan CA (1998). Accumulation of feruloyltyramine and p-coumaroyltyramine in tomato leaves in response to wounding. Phytochem 47:659-664.

Putter J (1974). Peroxidase, 685-690 p. In: Bergmeyer HU (Ed.). Methods of Enzymatic Analysis, Verlag Chemie, Weinhan.

Ruelas C, Tiznado-Hernandez ME, Sanches-Estrada A, RoblerBurgueno, MR, Troncoso-Rojas R (2006). Changes in phenolic acid content during Alternaria alternate infection in tomato fruit. J Phytopathol 154:236-244.

Stanetty P, Turner M, Mihovilovic M (2005). Synthesis of Pyrrolo 
$[2,3-d][1,2,3]$ thiadiazole-6-carboxylatesvia the Hurd-Mori Reaction. Investigating the Effect of the $N$-Protecting Group on the Cyclization. Molecules 10:367-375.

Sticher L, Mauch-Mani B, Metraux JP (1997). Systemic acquired resistance. Ann Rev Phytopathol 35:235-270.

Thordal-Christensen $\mathrm{H}$, Zhang Z, Wei Y, Collinge DB (1997). Subcellularlocalization of $\mathrm{H}_{2} \mathrm{O}_{2}$ in plants. $\mathrm{H}_{2} \mathrm{O}_{2}$ accumulation in papillae and hypersensitive response during the barley powdery mildew interaction. The Plant J 11:11871194.

Van Loon LC, VanStrienEA(1999). The families of pathogenesisrelated proteins, their activities, and comparative analysis of PR-1 type proteins. Physiol Mol Plant Pathol 55:85-97.

Van Loon LC (1997). Induced resistance in plants and the role of pathogenesis-related proteins. Eur J Plant Pathol 1103:753-765.

Vernooij B, Friedrich L, Ahl-Goy P, Staub T, Kessmann H, Ryals $\mathrm{J}$ (1995).2:6-Dichloroisonicotinic acid-induced resistanceto pathogens does not require the accumulation of salicylicacid. Mol. Plant-Microbe Interact 8:228-234.
Villano D, Fernandez-Pachon S, Troncoso AM, Garcia-Parrilla MC (2005).Comparison of antioxidant activity of wine phenolic compoundsand metabolites in vitro. Anal Chim Acta 538:391-398.

Ward ER, Uknes SJ, Williams SC, Dincher SS, Wiederhold DL, Alexander DC, Ahl-Goy P, Ryals JA (1991). Coordinate gene activity in response to agents that induce systemic acquired resistance. Plant Cell 3:1085-1094.

Yang LX, Wang RY, Ren F, Liu J, Cheng J, Lu YT (2005). AtGLB1 enhances the tolerance of Arabidopsis to hydrogen peroxide stress. Plant Cell Physiol 46:1309-1316.

Ye XS, Pan SQ, Kuc J (1990). Activity, isoenzyme pattem, and cellular localization of peroxidase as related to systemic resistance of tobacco to blue mold (Perosporu tabaciiza) and to tobacco mosaic virus. Phytopathol 80:1295-1298.

Younes M (1981). Inhibitory action of some flavonoids on enhanced spontaneous lipid peroxidation following glutathione depletion. Planta Medica 43:240-245.

Winkel-Shirley B (2002). Biosynthesis of flavonoids and effects of stress. Curr Opin Plant Biool 5:218-223. 